\title{
WSPÓŁCZESNY STUDENT W ŚWIECIE MOBILNYCH URZĄDZEŃ
}

\begin{abstract}
Streszczenie: Opracowanie dotyczy oceny stosowania najnowszych urządzeń mobilnych związanych z IT przez współczesnego studenta. System szkolny ulega ciągłym zmianom. Nauczyciele w zdecydowanej większości nastawieni są na klasyczne, tradycyjne prezentowanie i egzekwowanie wiedzy oraz umiejętności. Uczniowie zaś w dużej mierze korzystają z wiedzy dostępnej wirtualnie. Powoduje to rozdźwięk i utrudnia komunikację. Te same problemy występują również w środowisku akademickim. Badania przeprowadzone wśród studentów Uniwersytetu Technologiczno-Humanistycznego w Radomiu pokazują funkcjonowanie przyszłych nauczycieli w świecie cyfrowym.
\end{abstract}

Słowa kluczowe: urządzenia mobilne, życie studenta, edukacja

\section{WPROWADZENIE}

Zmienia się rola urządzeń, które jeszcze do niedawna kojarzyły się z pracą w zamkniętym pomieszczeniu. Komputer stacjonarny wypierany jest przez laptop, tablet lub smartfon. Telefon komórkowy nie służy tylko do rozmów i komunikacji SMS-owej, ale jako smartfon pełni prawie wszystkie funkcje personalnego komputera. Oznacza to jednocześnie permanentną obecność w przestrzeni wirtualnej.

Trudno sobie wyobrazić funkcjonowanie współczesnego studenta bez dostępu do urządzeń mobilnych. Bardzo często komunikacja w grupie studenckiej przebiega przede wszystkim w przestrzeni wirtualnej. Niniejsze opracowanie jest próbą oceny tego stanu rzeczy na podstawie badań przeprowadzonych wśród studentów radomskich. 


\section{PRZEMIANY WSPÓŁCZESNEJ SZKOŁY}

Czy można we współczesnej szkole stosować te same metody nauczania, te same podręczniki i te same zasady prawne, jakie obowiązywały kilkadziesiąt czy nawet kilkanaście lat temu? Odpowiedź na to pytanie nie powinna budzić większych wątpliwości. Nie można, gdyż każdego roku do szkół przyjmowane są dzieci i młodzież, dla których posługiwanie się różnymi urządzeniami technologii informacyjnej jest chlebem powszednim. Można tu przytoczyć sformułowane kilkanaście lat temu pojęcia o cyfrowych imigrantach i cyfrowych tubylcach - to pierwsze w odniesieniu do ludzi urodzonych przed 1980 rokiem, a to drugie do ludzi młodszych. Ci pierwsi to pokolenie, które jeszcze pamięta tradycyjną klasę szkolną z tablicą, ale również z mapami, przyrządami typu mikroskop, przedmiotami, którymi można było coś realnego wykonać. Ci drudzy dorastali w otoczeniu nowych technologii: komputerów, telefonów komórkowych, smartfonów, tabletów, urządzeń GPS itp., którzy wiele rzeczy potrafią wykonać, wykorzystując możliwości owych urządzeń. Te dwie generacje często spotykają się w instytucjach edukacyjnych, przy czym ci pierwsi są nauczycielami, rodzicami, trenerami, kierownikami, a drudzy uczniami, studentami, młodymi pracownikami. Na szczęście wymiana kadr wkrótce sprawi, że i jedni i drudzy będą komunikować się w sposób dla siebie zrozumiały.

Obecnie przed współczesną szkołą staje wyzwanie dostosowania procesu dydaktycznego do zmieniających się ram środowiskowych, w których funkcjonuje młody człowiek. Przemiany związane z rozwojem społeczeństwa informacyjnego, technologie, które odmieniły w sposób radykalny środowisko informacyjne i komunikacyjne ucznia i studenta - to wszystko ma istotny wpływ na przebieg całego procesu uczenia się i nauczania (Pulak 2010, s. 244).

Dzisiaj młodzi ludzie we wszystkim, co robią, pragną przede wszystkim wolności - nazywają się dziećmi sieci, dla których najważniejszą wartością jest wolność słowa, dostępu do informacji, kultury, ale także dopasowania elementów szkolnej edukacji do własnych potrzeb (Musiał 2013, s. 212). W konsekwencji potencjał współczesnego ucznia, który ukształtowała m.in. cyfrowa technologia, nie jest i nie może być niezauważony przez szkołę, która powinna angażować wychowanków, być miejscem tworzenia wiedzy, a nie jedynie jej przekazywania, a przede wszystkim, jak twierdzi pokolenie sieci:

nie być miejscem oddalonym od realnego świata. Dla wielu współczesnych nastolatków świat realny i wirtualny wzajemnie się przenikają, są czasami wręcz nierozróżnialne. Potrafią wiele czynności wykonywać jednocześnie i to im nie przeszkadza, a wręcz pomaga w koncentracji. Nie są w stanie za to przeczytać długiego tekstu w książce. (Kołodziejczyk, Polak 2011, s. 39-40). 
Przemiany zachodzące $\mathrm{w}$ sferze kultury, związane przede wszystkim $\mathrm{z}$ rozwojem telewizji, multimediów, „narzuciły” dzieciom audiowizualne doświadczanie otaczającego ich świata. Większość z nich korzysta na co dzień z wytworów o bardzo wysokiej i złożonej technologii i nie wyobraża sobie życia bez tych urządzeń. Coraz więcej dzieci już od pierwszej klasy szkoły podstawowej posiada własny telefon komórkowy, uznając go za dużą atrakcję, ale także wskaźnik wyróżniający oraz nobilitujący, zwłaszcza w grupie rówieśniczej. Jest to medium różniące się od pozostałych i odgrywa nieco inną rolę w życiu dzieci niż w świecie dorosłych. Dla dziecka nie jest narzędziem pracy, ale silną potrzebą, pragnieniem posiadania, rozrywką, symbolem przynależności do rówieśniczej grupy posiadaczy telefonów komórkowych (Izdebska 2009, s. 92-94). Obecnie posiadane przez dzieci w wieku szkolnym smartfony umożliwiają wykonanie większej liczby czynności, zarówno zabawowych, jak i edukacyjnych, z uwagi na stałe połączenie z Internetem i lepszą wizualizację otrzymywanych przekazów.

Coraz większa powszechność używania telefonów komórkowych przez gimnazjalistów składnia do refleksji o możliwości stosowania ich w edukacji szkolnej. Badania wstępne przeprowadzone przez Andrzeja Mamroła w gimnazjum w Opolu pokazały dużą powściągliwość ze strony nauczycieli wobec możliwości wykorzystywania telefonów komórkowych w procesie dydaktyczno-wychowawczym w szkole. Wynika to z małej wiedzy nauczycieli na temat najnowszych możliwości nowoczesnych aparatów, niebezpieczeństw „legalnego” używania telefonów, jak również z faktu, że uczniowie posiadają bardzo zróżnicowany technologicznie sprzęt (Mamroł 2014, s. 127-128).

W działaniach edukacyjnych i profilaktycznych dostęp do Internetu, w domu czy też za pośrednictwem smartfona, większości polskich nastolatków stwarza nowe wyzwania i problemy. Ważne jest, aby każdy młody użytkownik umiał z narzędzi IT korzystać świadomie i bezpiecznie. Jest to cel edukacji medialnej, której głównymi zadaniami stało się przygotowanie do właściwego odbioru mediów oraz posługiwania się tymi narzędziami w celu samorozwoju intelektualnego, zawodowego i społecznego (Ziębakowska-Cecot 2009, s. 108).

Symbolem najnowszych technologii IT jest niewątpliwie mobilność. Słowo to do niedawna oznaczało przede wszystkim aktywność, energiczne działanie, temperament, zaradność i ruchliwość. Są to niewątpliwie pożądane cechy uczniów czy też absolwentów szkół. Tacy młodzi ludzie świetnie funkcjonują w świecie cyfrowym, ale czasami mają wiele problemów, często też nie znajdują zrozumienia u nauczycieli. Na uwagę zasługują projekty, które próbują te bariery przełamać. Sukces takich przedsięwzięć zależy od osób odpowiedzialnych za zarządzanie szkołą, jak również, a może przede wszystkim, od zaangażowania i zainteresowania nauczycieli (Andrzejewski 2015, s. 13-15). 
W odniesieniu do współczesnych uczniów, pokolenia cyfrowych tubylców, powinno się stosować nowe koncepcje uczenia się. Wśród takich rozwiązań wymienia się m.in.:

- konektywizm, zakładający, że uczenie się powinno być procesem ciągłym, który dzięki nowym technologiom może przebiegać w dowolnym miejscu i w dowolnym czasie, jest zindywidualizowany;

- metody aktywizujące i zwiększające czynny udział uczących się w zajęciach dydaktycznych (np. metoda projektu, którą cechuje interdyscyplinarność i samodzielność podejmowania decyzji przez uczniów; metoda kształcenia wyprzedzającego, której istotą jest aktywne organizowanie i przyswajanie wiadomości przez uczniów przed lekcją w związku z zapowiedzianym tematem, który ma być omawiany na lekcji);

- instytucje, które nieodpłatnie udostępniają materiały edukacyjne ludziom na całym świecie (np. Akademia Khana - znana na całym świecie internetowa akademia, której misją jest zmiana edukacji tak, aby zdobycie wykształcenia umożliwić ludziom na całym świecie przez dostosowanie sposobów zdobywania wiedzy do zróżnicowanych norm i zwyczajów kulturowych; Polski Kanał Edukacyjny You Tube oferujący materiały edukacyjne z zakresu szkoły ponadgimnazjalnej, szkoły wyższej oraz kursy i szkolenia; TED - organizacja propagująca idee zmieniające świat) (Musiał 2015, s. 107-108).

\section{STUDENT W ŚWIECIE MOBILNYCH URZĄDZEŃ IT}

Wydawać by się mogło, że w procesie nauczania-uczenia się w szkołach wyższych środki IT są czymś naturalnym i powszechnie stosowanym. Z drugiej strony co jakiś czas pojawia się uczucie niedosytu czy wręcz nawet zawodu, że nowe technologie tak wolno rozprzestrzeniają się w środowisku uniwersyteckim. Dotyczy to wspomagania nauczania (e-learning, m-learning), edukacji mobilnej oraz porozumiewania się między studentami a kadrą naukowo-dydaktyczną, a także w obrębie społeczności studenckiej, zwłaszcza przy wykorzystaniu mediów społecznościowych.

Współczesne media są bardzo angażujące i wymagają nowych umiejętności zarówno od twórców przekazów medialnych, jak i ich odbiorców. W kulturze uczestnictwa niezbędne jest posiadanie różnych kompetencji społecznych. Korzystanie z różnorakich platform medialnych, mediów społecznościowych, sieci projektowych itp. wymaga nowych sposobów myślenia, innego niż wcześniej podejścia do poszukiwania informacji i przetwarzania wiedzy. Nie jest to łatwe i może generować efekt ograniczonej akceptacji dla zmian społecznych wywoła- 
nych dominacją nowoczesnych technologii. Tak naprawdę to nowe podejście do mediów powinno być ukształtowane wcześniej, w wieku szkolnym (Penkowska 2015, s. 225-226).

Mimo wielu doświadczeń i prób e-learning nie jest w pełni akceptowany w środowisku akademickim. Dotyczy to zarówno kadry nauczającej, obarczanej przygotowywaniem kursów online i prowadzeniem zajęć w tej formule, co zazwyczaj oznacza zwiększony nakład pracy, ale również studentów, którzy ten system nauczania przyjmują dość sceptycznie. Być może istnieje możliwość przełamania tego impasu i stworzenie połączenia (mostu) między nauczaniem klasycznym a nauczaniem zdalnym. Taką szansę stwarza inicjatywa powstała przed kilku laty pod nazwą Massive Open Online Courses (otwarte masowe kursy akademickie prowadzone przez Internet). W 2012 roku kilkanaście portali internetowych uczelni z USA zaoferowało bezpłatne kursy z różnych przedmiotów akademickich dla studentów z całego świata. Najbardziej popularnym kursem było wprowadzenie do sztucznej inteligencji (Introduction to Artificial Intelligence). Koncepcja MOOC's może stać się pomostem łączącym edukację oficjalną (prowadzoną przez instytucje) z edukacją nieformalną (indywidualną), umożliwić wykorzystanie potencjału naukowo-dydaktycznego znanych placówek akademickich i naukowych w celu nauczania ludzi z całego świata (Benedek 2014, s. 80-85).

Nauczanie zdalne mimo różnych przeszkód rozwija się i trudno oczekiwać, że współczesna szkoła może cofnąć swój rozwój i wrócić do klasycznego, tradycyjnego nauczania. Rozwój urządzeń IT idzie obecnie w stronę połączeń bezprzewodowych, co pozwala korzystać z zasobów edukacyjnych w dowolnym miejscu. Można w ten sposób mówić o m-learningu (mobile-learning). W tym celu trzeba oczywiście dysponować w każdej chwili sprzętem takim jak tablet, smartfon czy laptop z dostępem do Internetu. Od kilku lat powstają też aplikacje dostosowane do odpowiedniego sprzętu umożliwiające prezentację materiałów dydaktycznych na ekranach urządzeń mobilnych wraz z weryfikacją efektów uczenia się (Kupidura, Oparcik 2010, s. 331-334).

\section{BADANIA PRZEPROWADZONE WŚRÓD STUDENTÓW RADOMSKICH NA TEMAT WYKORZYSTYWANIA PRZEZ NICH URZĄDZEŃ MOBILNYCH IT}

Czy współcześni studenci korzystają w wystarczającym stopniu z urządzeń mobilnych w celach edukacyjnych, a także dla zaspokajania innych potrzeb? W jakim stopniu ich komunikacja $\mathrm{z}$ innymi ludźmi jest realna, a w jakim odbywa się w sieci za pośrednictwem portali społecznościowych? Czy zmiany ich zachowań 
społecznych są korzystne, czy też generują skutki negatywne? Odpowiedzi na te pytania pozwolą udzielić badania przeprowadzone w styczniu 2016 roku na grupie studentów radomskich.

Badaniom poddano 100 studentów Uniwersytetu Technologiczno-Humanistycznego w Radomiu. Były to dwie równe grupy: pierwszą stanowili studenci kierunku pedagogika (wszyscy z drugiego roku), a drugą studenci kierunku wychowanie fizyczne (z uwagi na niewielką liczbę ogólną studentów badani pochodzili ze wszystkich trzech lat studiów pierwszego stopnia). Na pedagogice przeważają kobiety - badaniu poddano 4 mężczyzn i 46 kobiet. Natomiast na wychowaniu fizycznym więcej jest mężczyzn - w badaniu udział wzięło 18 kobiet i 32 mężczyzn. W rzeczywistości mężczyzn na wychowaniu fizycznym jest procentowo więcej, ale ich frekwencja na zajęciach dydaktycznych jest zawsze dużo niższa niż kobiet. Ogólna liczba badanych to 64 kobiety i 36 mężczyzn. Średnia wieku studentów to 21 lat. Najstarsza badana studentka miała 28 lat, najmłodsi byli w wieku 19 lat. Jest jeszcze jedna istotna informacja. Większość badanych (80\%) to potencjalni przyszli nauczyciele. Wszyscy studenci na kierunku wychowanie fizyczne uzyskują kwalifikacje pedagogiczne, a większość ankietowanych studentek pedagogiki wybrała specjalność edukacja przedszkolna i wczesnoszkolna (30 osób). Większość badanych studentów to stali mieszkańcy Radomia - 54\%, $10 \%$ pochodzi z małych miast regionu, $21 \%$ to mieszkańcy wsi, aż $15 \%$ nie zaznaczyło żadnej odpowiedzi na to pytanie.

Stosowanie urządzeń IT często związane jest $\mathrm{z}$ budżetem czasu studenta, a także z jego różnymi formami spędzania wolnego czasu, dlatego też poproszono badanych o określenie, w jakim stopniu angażują się w wymienione aktywności. Można było wybrać następujące działania (formy): nauka lub praca zawodowa, codzienne obowiązki domowe, spotkania towarzyskie, aktywność ruchowa („sportowanie”), dbałość o własny wygląd, IT (komputer, tablet, smartfon, Internet), media klasyczne ( $\mathrm{TV}$, radio, gazety), czytanie książek, inne (należało wpisać, jakie). Respondenci mogli przypisać tym działaniom następujące odpowiedzi: „bardzo dużo”, „dużo”, „mało”, „zdecydowanie za mało”, „nie poświęcam w ogóle”.

Analiza wyników dotyczących budżetu czasu studenta przynosi ciekawe spostrzeżenia. Odpowiedź „nie poświęcam w ogóle” wybrana została tylko dla trzech opcji: czytanie książek (aż 12 osób), oglądanie telewizji (6 osób) oraz aktywność ruchowa (jedna osoba). Zwyczaj czytania książek zanika, gdyż aż 41 osób czyta mało, a 32 osoby czytają zdecydowanie za mało. Tylko 3 osoby czytają bardzo dużo, a 12 osób dużo. Wydawać by się mogło, że wskaźnik ten zaniżają studenci wychowania fizycznego. Okazało się to jednak nieprawdą. Wprawdzie w istocie osoby czytające bardzo dużo to studenci pedagogiki, ale wśród 12 studentów czytających dużo tylko połowa to studenci pedagogiki, zaś pozostali studiują wychowanie fizyczne. Ocena całej zbiorowości pokazuje, że najwięcej zwolenników 
(wzięto pod uwagę wskazanie „bardzo dużo”) ma aktywność ruchowa (32 osoby), korzystanie ze środków IT (31 osób) oraz dbanie o własny wygląd (26 osób). Gdyby wziąć pod uwagę dodatkowo wskazania "dużo” i je zsumować z „bardzo dużo”, to okazałoby się, że hierarchia ulegnie zmianie. Na pierwszym miejscu będzie korzystanie z urządzeń IT (79 wskazań), na drugim dbanie o własny wygląd (78), a na trzecim aktywność ruchowa (63). Na wykresie 1 przedstawione zostały szczegółowe wyniki badań w tym zakresie.

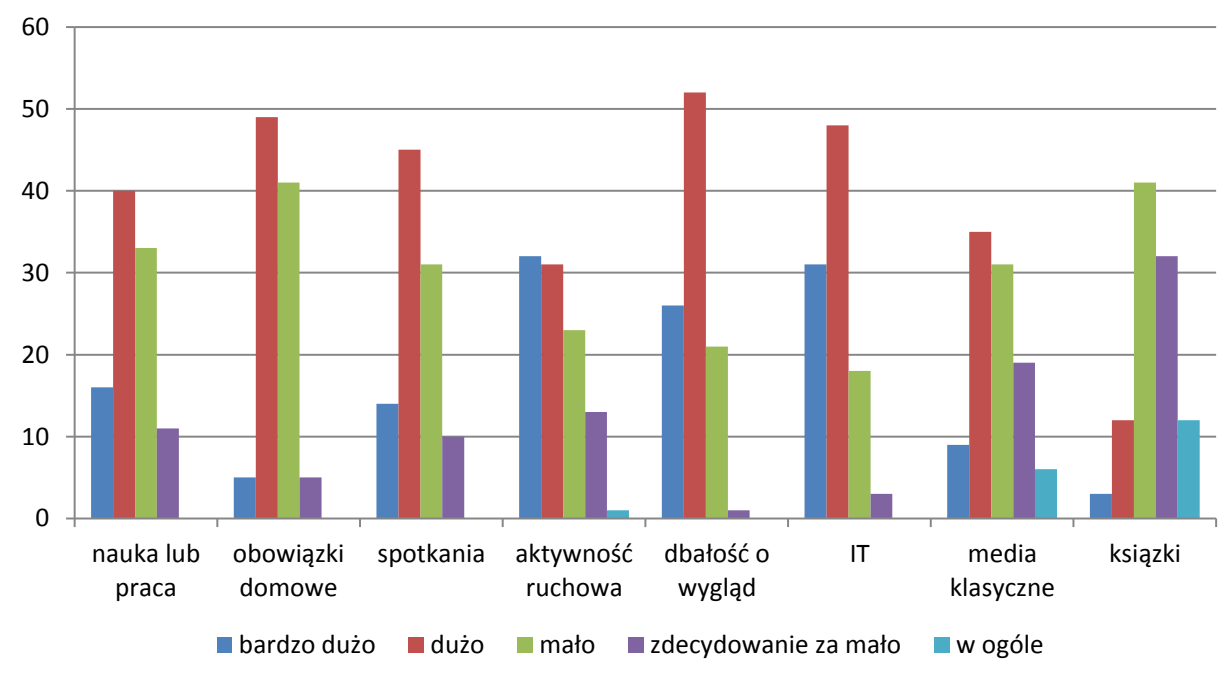

Wykres 1. Czas poświęcony na różne działania

Nieco inne wyniki przynosi analiza wyborów w grupach studentów pedagogiki i wychowania fizycznego. Studenci pedagogiki najwięcej czasu poświęcają na korzystanie z urządzeń IT (łącznie 45 wskazań, tj. 90\%, na „bardzo dużo” i „dużo”) i dbanie o własny wygląd (37 wskazań, tj. 74\%). Z kolei studenci wychowania fizycznego najwięcej czasu poświęcają na aktywność ruchową (46 wskazań, tj. 92\%) i na korzystanie ze środków IT (34 wskazania, tj. 68\%). Wyniki te zgodne są z oczekiwaniami. Nic dziwnego, że studenci wychowania fizycznego dużą wagę przykładają do aktywności ruchowej, a z kolei studenci (są to głównie kobiety) pedagogiki do dbania o własny wygląd. Zastanawiające jest, że zarówno jedna, jak i druga grupa tak wiele czasu poświęca korzystaniu ze środków IT. Może to wynikać z tego, że studenci pedagogiki w rzeczywistości wirtualnej czytają, wymieniają informacje, blogują, wymieniają się filmami i muzyką, zaś studenci wychowania fizycznego śledzą wydarzenia sportowe, jedni i drudzy wykorzystują także sieć do nauki i pracy. 
Odpowiedzi na kolejne pytanie pozwolą ustalić, jakich urządzeń najczęściej używają studenci, aby skorzystać z Internetu. Okazuje się, zgodnie z trendami światowymi, że komputer stacjonarny ma coraz mniej użytkowników, ale również tablet nie stał się urządzeniem często stosowanym przez studentów. Studenci zaledwie w 34 przypadkach posługiwali się komputerem stacjonarnym jako urządzeniem najczęściej lub w drugiej kolejności używanym w dostępie do Internetu. Jeszcze mniej z nich posługuje się w tym celu tabletem (zaledwie 15 przypadków). Najczęściej używany jest smartfon z wykorzystaniem wi-fi (70 wskazań), laptop (53 wskazania) i smartfon $z$ dostępem przez sieć komórkową (52 wskazania). Oznacza to, że nie wszyscy studenci, lecz tylko nieco ponad połowa ma stałe połączenie z Internetem za pomocą smartfona, za to zdecydowana większość z nich korzysta z coraz liczniejszych możliwości połączenia z wykorzystaniem wi-fi. Nie zauważa się większych różnic, jeśli chodzi o dostęp do Internetu w zależności od kierunku studiów. Jedyna różnica polega na tym, że stosunkowo dużo studentów wychowania fizycznego używa jeszcze komputerów stacjonarnych do korzystania z zasobów Internetu. Na wykresie 2 przedstawione zostały szczegółowe wynik badania.

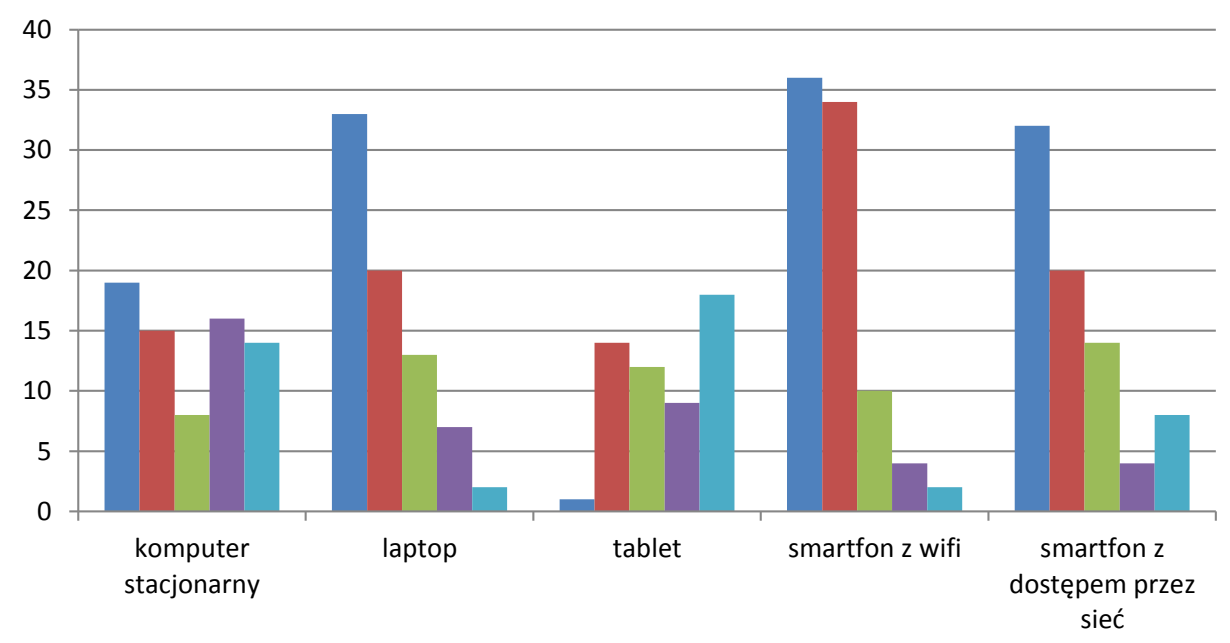

wsk 1 wsk 2 wsk 3 wsk 4 wsk 5

Wykres 2. Dostęp do Internetu

Następne pytanie dotyczyło tego, ile czasu studenci poświęcają w Internecie na naukę (pracę zawodową), a ile na cele prywatne. Zgodnie z oczekiwaniami dłużej zajmują się realizacją celów prywatnych, średnio jest to blisko 3 godziny 
(studenci pedagogiki ok. 3 godzin i 12 minut, a studenci wychowania fizycznego blisko 2 godziny i 40 minut). Studenci wychowania fizycznego nauce (pracy) poświęcają tylko 1 godzinę i 16 minut, a studenci pedagogiki nieco ponad 2 godziny. Widać więc, że studenci pedagogiki dłużej „siedzą w Internecie” niż ich koledzy z wychowania fizycznego, chociaż rekordzistą jest student tego drugiego kierunku, który deklarował spędzanie 12 godzin dziennie dla celów prywatnych w Internecie. Nie brak było też odpowiedzi opisowych typu „bardzo dużo” lub „,”.

W kolejnym pytaniu respondenci mogli wskazać, z czym najbardziej kojarzy im się Internet. Najwięcej z nich określiło globalną sieć jako źródło informacji (53 wskazań z wagą 1 i 31 wskazań z wagą 2), następnie jako kontakt ze światem (43 i 30 wskazań odpowiednio) oraz jako źródło rozrywki (23 i 34). Wyniki przedstawia wykres 3 .

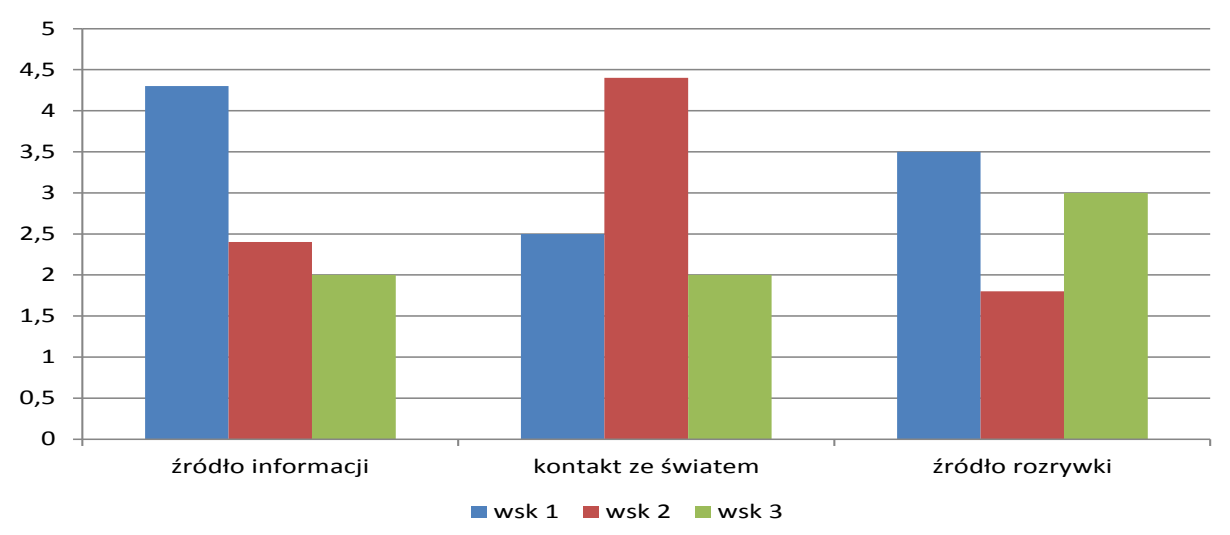

Wykres 3. Z czym najbardziej kojarzy się Internet?

Proszeni byli również o odpowiedź na pytanie, jakie najważniejsze cechy charakteryzują dostęp do Internetu. Zdecydowana większość wskazała dostępność w każdym miejscu (łącznie 86 wskazań z wagą 1 lub 2) i wygodę (78 wskazań). Na szczęście studenci nie w pełni ufają informacjom z sieci, gdyż wiarygodność uzyskała 37 wskazań z najwyższymi wagami, podobnie jak prostota (38). Na wykresie 4 przedstawione zostały te informacje. 


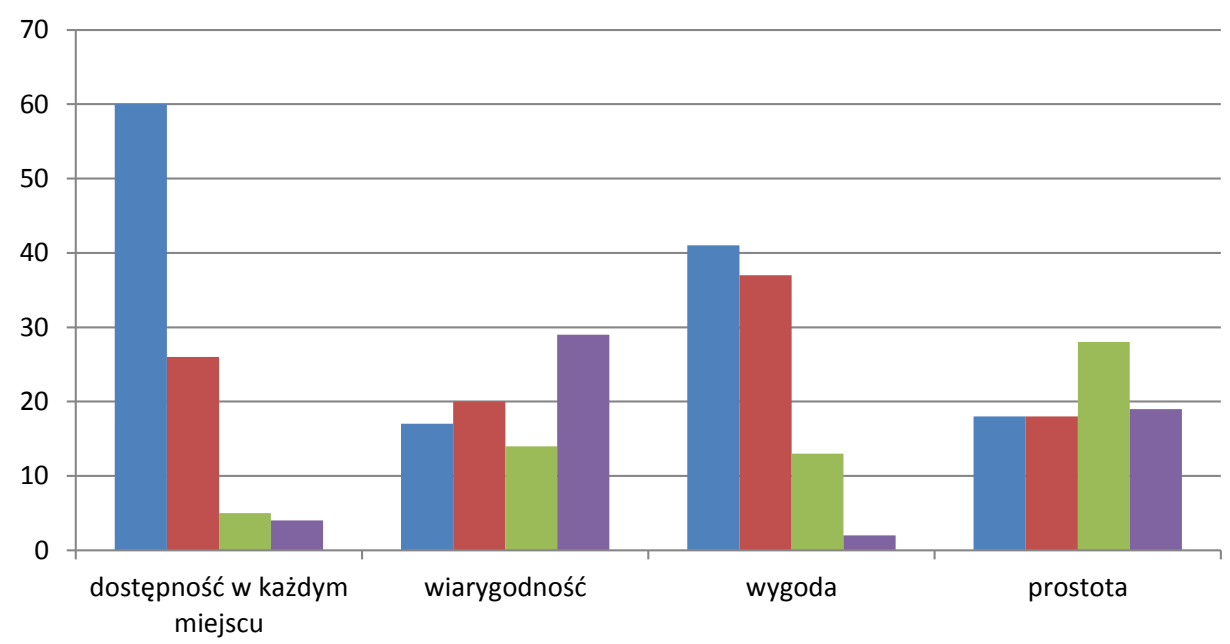

wsk 1 wsk 2 wsk 3 wsk 4

Wykres 4. Cechy Internetu

Typowym parametrem określającym stopień zaawansowania społeczeństwa informacyjnego jest wykorzystywanie Internetu do zamawiania towarów, zakupów i innych usług. Okazuje się, że większość studentów sporadycznie korzysta z takich możliwości (62 wskazania), tylko 26 osób wykorzystuje te usługi często.

Smartfon to praktycznie urządzenie wykorzystywane przez studentów powszechnie i bardzo często. Prawie wszyscy ( 99 osób) wykorzystują go jako typowy telefon komórkowy (do rozmów i SMS-ów), na drugim miejscu znalazło się korzystanie z portali społecznościowych (82). Ponad połowa wskazań dotyczyła słuchania muzyki (65) i szukania informacji na temat rozkładu jazdy autobusów i pociągów (63). Szczegóły przedstawia wykres 5.

Facebook jest obecnie najpopularniejszym portalem społecznościowym zarówno w świecie młodzieży, jak i dorosłych. Korzystają z niego praktycznie wszyscy studenci. W badaniach tylko jedna osoba zadeklarowała, i to do końca nie wiadomo, czy wiarygodnie, że nie korzysta z Facebooka, zaś 97 osób wykorzystuje ten portal do kontaktów grupowych. Coraz łatwiej jest nawiązać kontakt z grupą studencką przez Facebooka aniżeli pocztę elektroniczną. Wśród badanych respondentów tylko niespełna trzecia część (31 osób) zamieszcza swoje zdjęcia i opisuje na tym portalu ciekawe wydarzenia.

Popularny wśród polityków Twitter nie zaistniał w środowisku radomskich studentów. Tylko jedna osoba korzysta z niego czynnie oraz biernie i jedna wyłącznie biernie. Co ciekawe, są to dwaj studenci (mężczyźni) pedagogiki. Podobne 
wyniki przyniosły badania studentów krakowskich w 2012 roku - 95\% nie znało zjawiska tweetowania (Musiał 2013, s. 212).

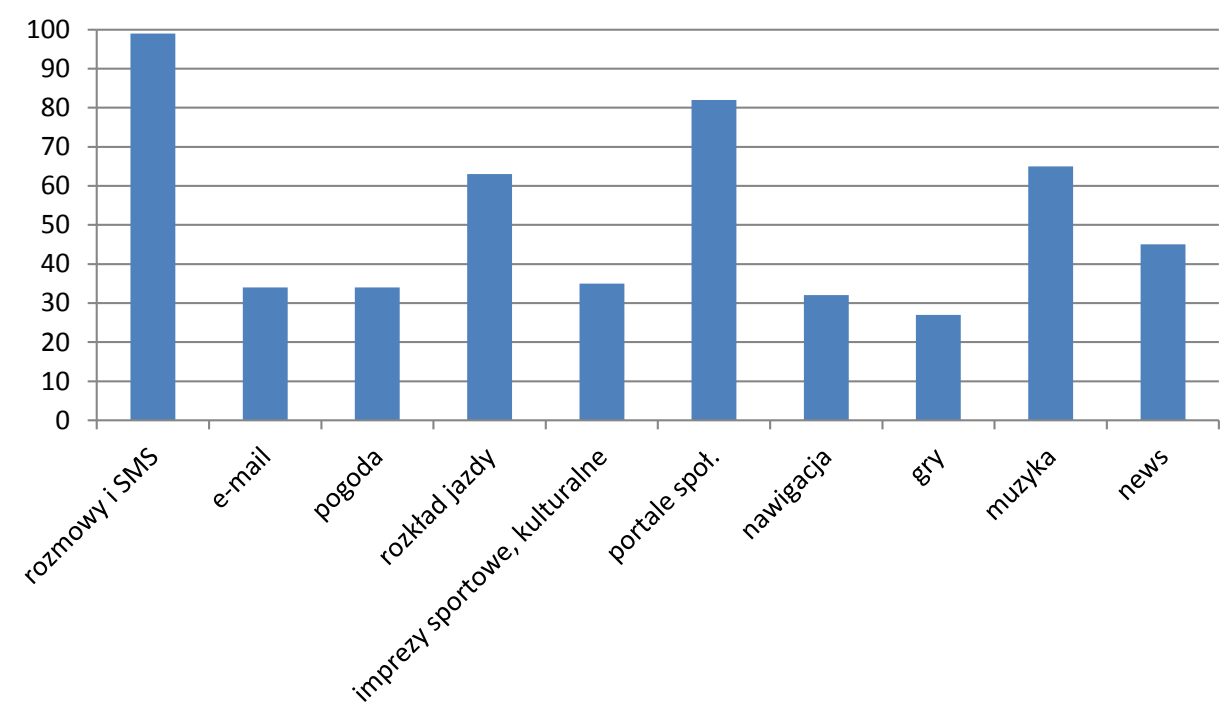

Wykres 5. Do czego wykorzystywany jest smartfon?

Permanentne korzystanie z telefonu komórkowego (smartfona) to cecha charakterystyczna młodych ludzi nie tylko w Polsce, ale na całym świecie. Zawsze należy podchodzić do deklarowanej przez respondentów ilości czasu z nieufnością, zwłaszcza gdy pytani odpowiadają 24 godziny. Oczywiście jest to niemożliwe, ale oznaczać może zasypianie $z$ telefonem w zasięgu ręki i po przebudzeniu natychmiastowe włączenie tego urządzenia. Średni czas korzystania ze smartfona dziennie to 6 godzin i 25 minut, z tabletu 2 godziny i 33 minuty, a z laptopa 2 godziny i 55 minut.

Kolejne pytania dotyczyły znajomości funkcji i umiejętności ewentualnego posługiwania się niektórymi urządzeniami związanymi z IT. Zdecydowana większość studentów przy jeździe samochodem wykorzystuje urządzenie GPS (36 wskazań) lub aplikację GPS w smartfonie (33), niewiele (tylko 10) korzysta z tradycyjnych map i planów, a 28 osób nie korzysta z niczego. Kilka osób korzysta z kilku pomocy. Kilkanaście osób wie, co to jest smartwatch (zegarek kompatybilny ze smartfonem) i niespełna 10 osób (prawie wszyscy z wychowania fizycznego) ma to urządzenie lub go używało. Trzynaście osób posługiwało się kamerką sportową (w tym osób 9 z wychowania fizycznego). Najbardziej typowe użycie to podczas jazdy na nartach, rzadziej na rowerze, w basenie lub podczas jazdy 
konnej. Niektórzy nawet wymienili najbardziej znaną markę, jaką jest Go Pro. Dwadzieścia osób widziało działanie drona, najczęściej na weselach, imprezach sportowych itp. Opaski sportowej używało blisko 10 studentów wychowania fizycznego. Ogółem wie, do czego służą, co czwarty respondent. Generalnie znajomość wybranych nowych urządzeń związanych z IT nie jest najlepsza wśród studentów radomskich.

Następne pytanie dotyczyło oceny wiarygodności informacji pozyskiwanych z różnych źródeł. Największym uznaniem cieszą się informacje pozyskiwane z książek (średnia 3,89 w skali od 0 do 5), z rozmów bezpośrednich, twarzą w twarz $(3,86)$ oraz z radia publicznego (3). Najmniej wiarygodna jest telewizja komercyjna $(1,68)$, następnie radio komercyjne $(2,14)$, telewizja publiczna $(2,29)$, portale społecznościowe $(2,61)$ i gazety $(2,83)$. Cieszy taka ocena mediów. Szczegółowe wyniki przedstawione zostały na wykresie 6 .

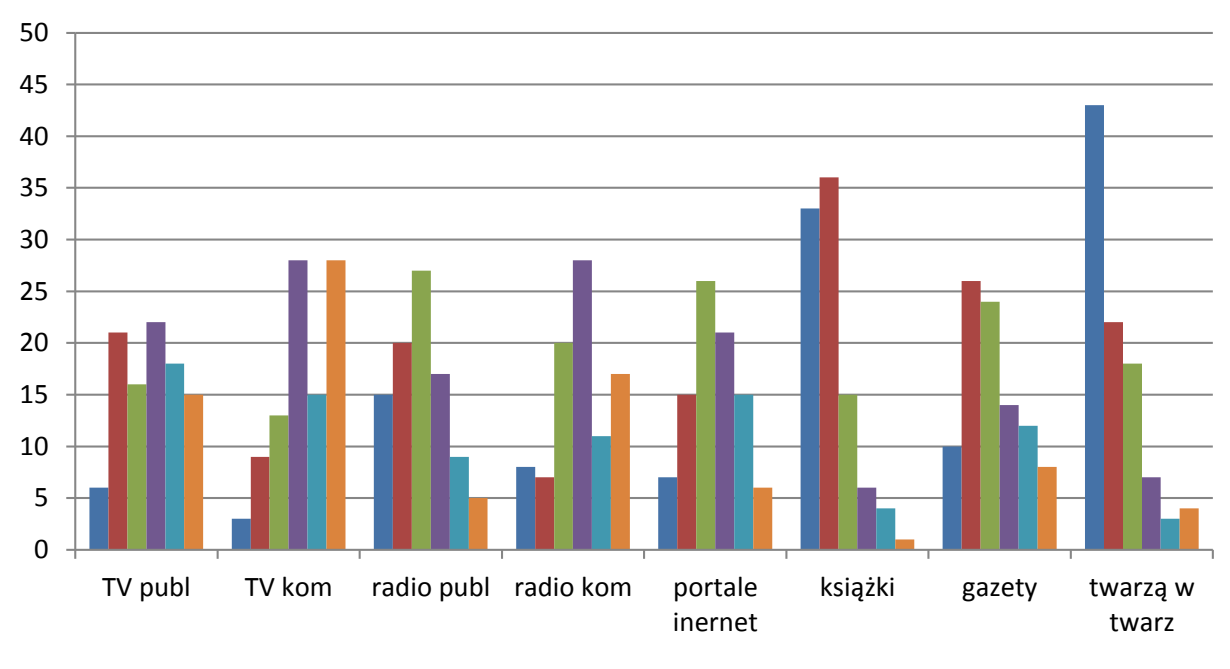

wsk 5 wsk 4 wsk 3 wsk 2 wsk 1 wsk 0

Wykres 6. Wiarygodność informacji pozyskiwanych z różnych mediów

Ostatnie pytanie dotyczyło negatywnych skutków, jakie może przynieść częste używanie urządzeń mobilnych. Szczegółowe wyniki przedstawia wykres 7. Studenci zauważają podstawowy problem, jakim jest uzależnienie od urządzeń mobilnych. Zdecydowana większość z nich nie wyobraża już sobie bez nich życia. Posługują się nimi prawie w każdej sytuacji i w każdych okolicznościach. Drugą zauważoną niedogodnością jest ciągły „niedoczas”, będący skutkiem poświęcania dużej ilości czasu „siedzeniu w Internecie”. Blisko 50\% respondentów zauważa też zanik 
więzi, ograniczenie bezpośrednich rozmów na rzecz przebywania w społeczności wirtualnej oraz fakt, że „sieć nie zapomina” - błędy kiedyś popełnione mogą zostać w każdej chwili przypomniane i często wykorzystane przeciwko osobie, która dawno mogła już o tym zapomnieć. Zastanawia tak mała liczba wskazań dotyczących inwigilacji. Czyżby studenci nie rozumieli słowa, które na trwałe weszło do dysput politycznych w naszym kraju?

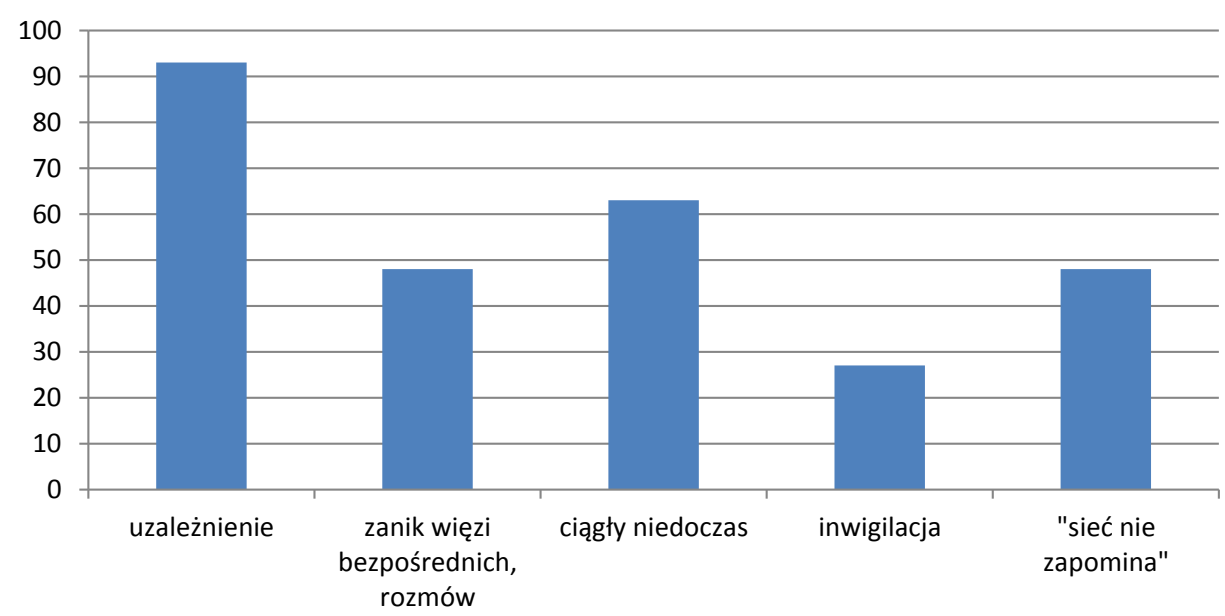

Wykres 7. Negatywne skutki częstego stosowania urządzeń mobilnych

\section{PODSUMOWANIE}

Współczesny student żyje w świecie mediów, korzysta z najnowszych urządzeń związanych z IT. Patrzy na świat z perspektywy portalu społecznościowego, ale jednocześnie ma świadomość zagrożeń z nadmiernego stosowania mobilnych urządzeń. Wie, że są największymi złodziejami czasu, zdaje sobie sprawę, że najbardziej wiarygodne informacje znaleźć można w książkach i gazetach, w których sprawdzono poprawność.

\section{LITERATURA}

Andrzejewski D., 2015, Mobilny uczeń - mobilny nauczyciel, czyli po co szkole technologia. W: J. Morbitzer, D. Morańska, E. Musiał (red.), Człowiek. Media. Edukacja. Dąbrowa Górnicza, Wyższa Szkoła Biznesu w Dąbrowie Górniczej. 
Benedek A., 2014, MINDTHEGAPP ${ }^{T M}$ : Connecting Global Educators and Mobile Learners. W: V. Stoffova (red.), New Technologies in Science and Education XXVI. DIDMATTECH 2013. Gyor, University of West Hungary Press.

Izdebska J., 2009, Telefon komórkowy i jego rola w życiu współczesnych dzieci-wyzwaniem dla edukacji medialnej. W: J. Morbitzer (red.), Komputer w edukacji, 19. ogólnopolskie sympozjum naukowe. Kraków, Katedra Technologii i Mediów Edukacyjnych Uniwersytetu Pedagogicznego.

Kołodziejczyk W., Polak M., 2011, Jak będzie zmieniać się edukacja? Wyzwania dla polskiej szkoły i ucznia. Warszawa, Instytut Obywatelski.

Kupidura T., Oparcik W., 2010, M-learning. W: H. Bednarczyk, E. Sałata (red.), Education and technology. Edukacja i technika. Radom, Politechnika Radomska.

Mamroł A., 2014, Telefon komórkowy - szanse i zagrożenia w edukacji uczniów szkót gimnazjalnych. W: K. Denek, A. Kamińska, P. Oleśniewicz (red.), Edukacja jutra. Aspekty edukacji szkolnej. Sosnowiec, Oficyna Wydawnicza Humanitas.

Musiał E., 2015, Media społecznościowe - narzędzie ucznia cyfrowej szkoły. W: K. Denek, A. Kamińska, P. Oleśniewicz (red.), Edukacja jutra. Role nauczyciela w edukacji szkolnej. Sosnowiec, Oficyna Wydawnicza Humanitas.

Musiał E., 2015, Rozpoznanie potrzeb edukacyjnych cyfrowych tubylców. W: K. Denek, A. Kamińska, P. Oleśniewicz (red.), Edukacja jutra. Nowe technologie w kształceniu. Sosnowiec, Oficyna Wydawnicza Humanitas.

Penkowska G., 2015, E-learning w dobie MOOC's. W: J. Morbitzer, D. Morańska, E. Musiał (red.), Człowiek. Media. Edukacja. Dąbrowa Górnicza, Wyższa Szkoła Biznesu w Dąbrowie Górniczej.

Pulak I., 2010, Wirtualne społeczności edukacyjne jako przestrzeń działań nauczyciela i ucznia. W: H. Bednarczyk, E. Sałata (red.), Education and Technology. Edukacja i technika. Radom, Politechnika Radomska.

Ziębakowska-Cecot K., 2009, Rozwój społeczeństwa informacyjnego a kompetencje nauczycieli. W: E. Sałata (red.), Problemy dokształcania i doskonalenia zawodowego nauczycieli. Radom, Politechnika Radomska.

\section{MODERN STUDENT IN THE WORLD OF MOBILE DEVICES}

Abstract: The content of the study is to assess the use of the latest mobile devices associated
with IT for the modern student. School system is in constant state of flux. The majority of
teachers focus on the traditional presentation and enforcement of knowledge and skills, while
the majority of students benefit greatly from the knowledge available virtually. It leads to
the considerable gap and makes mutual communication and understanding more difficult. 
The same problems also occur in an academic environment. Research conducted among the students of the University of Technology and Humanities in Radom show the functioning of future teachers in the digital world.

Keywords: mobile devices, student life, education 